\title{
Comparison of Self-levelling Underlayment to Traditional Methods Used in Brazil
}

\author{
Guilherme Figliuzzi $^{1}$, Elaine Vazquez ${ }^{2}$, Justino Nobrega ${ }^{3}$, João dos Santos ${ }^{4}$ and Lais Alves ${ }^{5}$ \\ 1. Department of Civil Engineering, Federal Center of Technological Education Celso Suckow da Fonseca, Brazil \\ 2. Department of Civil Construction, Federal University of Rio de Janeiro, Rio de Janeiro, RJ, 21941-909, Brazil \\ 3. DVSST, Department Post Graduate Studies on Safety Engineering, Federal University of Rio de Janeiro, Rio de Janeiro, RJ, \\ 21941-909, Brazil \\ 4. Department of Civil Engineering, Federal Center of Technological Education Celso Suckow da Fonseca, Brazil \\ 5. Department of Civil Engineering, Federal Center of Technological Education Celso Suckow da Fonseca, Rio de Janeiro, RJ, \\ 20271-110, Brazil
}

\begin{abstract}
Between 2005 and 2015, the Brazilian real estate market experienced strong growth, driven by the stable scenario of the Brazilian economy and policies to encourage real estate credit. With this demand, the companies of the sector sought to be more competitive in the market. One of the measures adopted is the search for more efficient executive processes. While the traditional manual methodology for underlayment predominates in the country's construction sites, a self-levelling underlayment presents a tendency towards mechanization of executive construction procedures. This paper aims to present a case study of a residential construction in Rio de Janeiro, which used self-levelling underlayment technology. Comparisons regarding cost and productivity of both methodologies were made to evaluate the viability of the self-levelling underlayment in future construction sites. Data obtained from other constructions were used to estimate the productivity and cost of the traditional underlayment levelling. The results demonstrate that the use of self-levelling underlayment has potential to be widespread and used in the constructions in Brazil.
\end{abstract}

Key words: Traditional levelling underlayment, self-levelling underlayment, cost, productivity.

\section{Introduction}

According to British Standard 8204-1:2008 [1] the underlayment consists of layer(s) of mortars or filler applied on the slab, ground or on an intermediate layer of insulation or waterproofing. Its properties, functions and the materials involved in the production of the subfloor depend on the characteristics of the desired flooring system.

Fiorito [2] describes that the floor is composed of numerous layers as represented, such as: slab or simple concrete ballast, cement paste layer, layer of mortar for regularization, underlayment, layer of adhesive mortar with uniform thickness of 3 to $6 \mathrm{~mm}$ (depending on the surface dimensions of the ceramic part) and ceramic

Corresponding author: Lais Amaral Alves, M.Sc., research fields: materials, and civil engineering. coating.

According to the Brazilian Standard NBR 15573-3:2013 [3], the underlayment is a stratum with the functions of regularizing the substrate (concrete slab), providing a uniform surface of support, cohesive, adhered or not, and suitable to the finishing layer, and may eventually serve as a layer of inlay, slope or declivity. This layer will serve as the basis for the laying of some floor covering, such as porcelain tile. In areas where there is presence of water due to rain (open areas) or personal use (shower), it is necessary that this subfloor layer has a slight declivity, to direct the water to a point of drain.

The underlayment has several functions, among which can be highlighted: to enable unevenness between environments, provide declivity for water flow, regularize the base for the floor covering, support 
and fixation of floor coverings and their components of installations, serve as an impermeable barrier, act as thermal and/or acoustic insulation [4].

The most common method to obtain substrate regularization is through the traditional underlayment, a rudimentary procedure in which the mortar is prepared at the site of execution by a team of construction workers. As the mortar is prepared in situ, there is a generation of very large construction waste during the process.

As an alternative, the self-leveling underlayment uses self-leveling mortar, which is pumped to the application site and launched by a hose, thereby avoiding the accumulation of on-site waste such as cement bags. In this more modern process, one can observe a significant increase of the work productivity.

The self-leveling mortar is the raw material for the self-leveling underlayment. It falls within the classification of fluid mortar. The proposal of self-leveling mortar, also known as self-squeezing mortar, is to allow adequate molding, free of defects resulting from failure of application or inadequate molding technique, without requiring high qualification of the worker [5].

The use of the self-leveling underlayment to regularize the structure will replace the traditional underfloor method, which depends on labor effort and has a complex logistics due to the need of all materials in loco and the waste generated from this activity, requiring the support of a rack or manual lifting of the materials. The self-leveling mortar arrives at site by the application of a pumping, similar to the concrete, with a pipe already pre-fixed in the construction site and launched by a pump. The mortar is generated in a concrete plant, and arrives at the site through a cement mixer truck, which avoids the generation of construction waste at the place of application. With this, the work remains cleaner and with less request of the equipment's.

The execution of the regularization of the concrete base by self-leveling underlayment is a procedure relatively new in construction sites. However, it is already seen as an efficient practice in terms of productivity, cost and less generation of waste. Although the self-leveling concrete has a higher material cost than conventional concrete, the cost of its launch is lower, thus reducing direct and indirect costs such as labor, housing, transportation, food, personal protective equipment, energy, uniforms, health plan etc. [6].

The objective of this work is to present in detail the procedures for the execution of underlayment using self-leveling mortar, showing the prerequisites for starting the service, the stages of launching, the work involved, the necessary equipment and the cure of the mortar. In addition, it aims to establish a comparison with the conventional method of execution for this service, highlighting the advantages and disadvantages of each process. Finally, a case study is presented about a real estate project in Rio de Janeiro, which used the self-leveling underlayment at its site, analyzing and evaluating productivity gains and cost reduction.

\section{Case Study}

The case study for this research is a multifamily residential condominium, located in Barra da Tijuca neighborhood in the city of Rio de Janeiro. The condominium consists of 5 towers of 17 floors, a floor of common use and another 3 floors of garage.

The total quantity of underlayment in this condominium was approximately $54,500 \mathrm{~m}^{2}$. The self-leveling underlayment was chosen over the conventional method, because this innovative methodology showed improvements in terms of productivity, cost and quality in previous studies. All the mortar used was produced by the internal concrete plant. The subfloors of the bathrooms and balconies were not made with self-leveling mortar because of the declivity necessary for the water to drain. The mixtures used on the condominium are show in Table 1. 


\section{Discussion}

\subsection{Productivity}

In terms of productivity, the use of self-leveling underlayment was satisfactory. As an example, the time it takes to execute a floor of one of the towers, with $498.51 \mathrm{~m}^{2}$ of underlayment to be executed is shown in Table 2.

The team assigned to perform the service consisted of 1 person in charge, 1 pump operator and 4 construction workers. Considering the beginning of the unloading at 12:30 and the end at 16:35 and adding 30 minutes due to the final preparation of the pavement, a productivity of $498.51 \mathrm{~m}^{2}$ was reached in 4 hours and 35 minutes, which is equivalent to approximately $109 \mathrm{~m}^{2}$ per $h$. The assembly time of the pumping system is not considered since the mortar has already been pre-assembled, connecting the place where the stationary pump will be positioned to the discharge site. On the day of each execution, while the mortar was dosed at the concrete plant, the launching staff extended the piping to the upper deck, taking an average of 20 minutes to complete the extension. It should also be considered that each tower of the condominium executed the launch of self-leveling underlayment once a week, since it depended on the execution of predecessor activities, such as the marking of the first masonry course and the company responsible for the launch only made available a single team to meet the demand of the 5 towers of the condominium.

Analyzing previous studies, it is possible to establish the productivity of a conventional underlayment execution team as $2.5 \mathrm{~m}^{2}$ per $\mathrm{h}$, considering a team of 2 construction workers. To perform a more reliable comparative analysis, it is considered a traditional underlayment team of 6 construction workers, and a productivity of $7,5 \mathrm{~m}^{2}$ per $\mathrm{h}$. Considering the above effectiveness for both teams, and a period of analysis of 17 weeks, Fig. 1 establishes a comparison for each method and Fig. 2 shows the graph for productivity for these methodologies.

\subsection{Cost}

For the cost analysis, data from previous projects were used to obtain the cost of labor and material of the traditional underlayment. The management of the enterprise set up a competition framework for contracting the company that would be responsible for launching the self-leveling subfloor, as shown in Table 3 for mobilization of team and equipment and for the self-leveling underlayment launch. Fig. 3 presents the total cost (mobilization/demobilization plus launch of the self-leveling underlayment) for the four companies consulted. The company chosen to launch the underlayment was Company 4, which was responsible only for supplying the workforce. The self-leveling mortar was supplied by the inner concrete center of the construction site.

Table 1 Self-leveling mortar mixtures.

\begin{tabular}{llll}
\hline Material & & Mixture & Productivity \\
\hline Cement & CP III-40 (HOLCIM) & 1 & 0,3333 \\
Fine aggregate 1 & Votorantim (ME = 2,68) & 0,717 & 0,2675 \\
Fine aggregate 2 & Natural sand mineramix (ME = 2,66) & 2,867 & 1,0779 \\
Additive 1 & TEC-MULT 900 LF SP (RHEOSET) & 0,0080 & 0,0080 \\
Water & Potable & 0,717 & 0,717 \\
\hline
\end{tabular}

Table 2 Beginning and end of unloading of mortar.

\begin{tabular}{llll}
\hline Date: 25/09/2014 & Concrete-mixer truck 1 & Concrete-mixer truck 2 & Concrete-mixer truck 3 \\
\hline Beginning of unloading & $12: 30$ & $14: 10$ & $16: 00$ \\
End of unloading & $13: 10$ & $15: 10$ & $16: 35$ \\
\hline
\end{tabular}




\begin{tabular}{|c|}
\hline Self-leveling underlayment \\
\hline 17 ㅇ Pav. \\
\hline 16 Pav. \\
\hline 15ㅇ Pav. \\
\hline 14ㅇ Pav. \\
\hline 13ㅇ Pav. \\
\hline 12ㅇ Pav. \\
\hline 11ㅇ Pav. \\
\hline 10ㅇ Pav. \\
\hline 9 Pav. \\
\hline 8ㅇ Pav. \\
\hline 7ㅇ Pav. \\
\hline 6ㅇ Pav. \\
\hline 5ㅇ Pav. \\
\hline 4ㅇ Pav. \\
\hline 3ㅇ Pav. \\
\hline 2ㅇ Pav. \\
\hline 1ㅇ Pav. \\
\hline
\end{tabular}

\begin{tabular}{|c|}
\hline $\begin{array}{c}\text { Traditional underlayment } \\
\text { method }\end{array}$ \\
\hline 17ㅇ Pav. \\
\hline 16 Pav. \\
\hline 15 Pav. \\
\hline 14 Pav. \\
\hline 13ㅇ Pav. \\
\hline 12 Pav. \\
\hline 11 Pav. \\
\hline 10 Pav. \\
\hline 9 Pav. \\
\hline 8 Pav. \\
\hline 7ㅇ Pav. \\
\hline 6 Pav. \\
\hline 5 Pav. \\
\hline 4 Pav. \\
\hline 3 Pav. \\
\hline 2 Pav. \\
\hline 1ㅇ Pav. \\
\hline
\end{tabular}

\begin{tabular}{|l|l|}
\hline \multicolumn{2}{|c|}{ Label } \\
\hline Underlayment executed: \\
\hline
\end{tabular}

Fig. 1 Comparative graph for the underlayment methodologies.

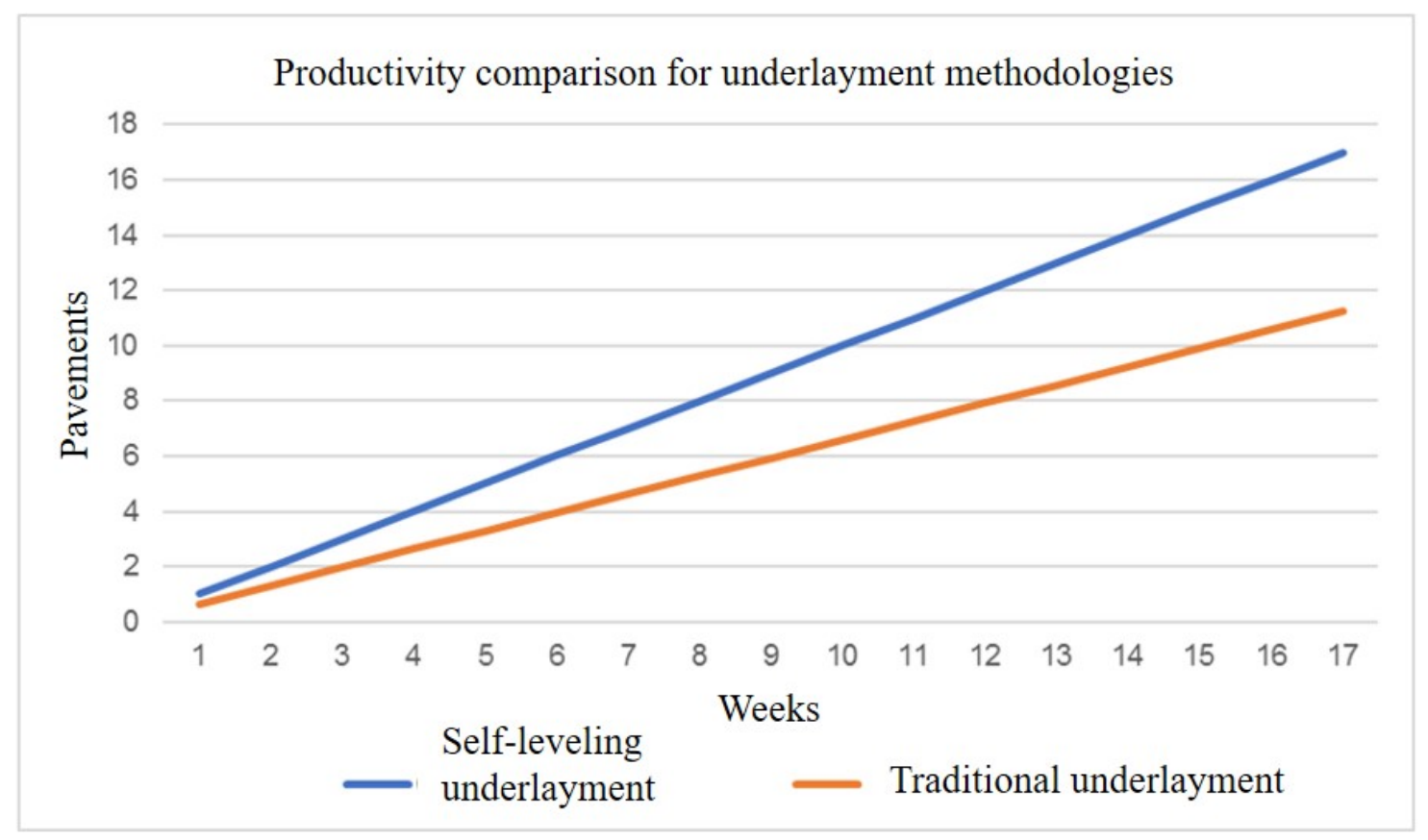

Fig. 2 Comparative for self-leveling and traditional method for underlayment on 17 weeks. 
Table 3 Comparison for mobilization/demobilization of team and equipment.

\begin{tabular}{llll}
\hline Company name & Total price for mobilization (BRL) & $\begin{array}{l}\text { Unit price for self-leveling } \\
\text { underlayment }\end{array}$ & $\begin{array}{l}\text { Total price for } 54,500.00 \mathrm{~m}^{2} \text { of } \\
\text { underlayment }\end{array}$ \\
\hline Company 1 & 7,000.00 & 22.90 & $1,248,050.00$ \\
Company 2 & N/A & 18.30 & $997,350.00$ \\
Company 3 & 1,000.00 & 23.80 & $1,297,100.00$ \\
Company 4 & N/A & 18.00 & $981,000.00$ \\
\hline
\end{tabular}

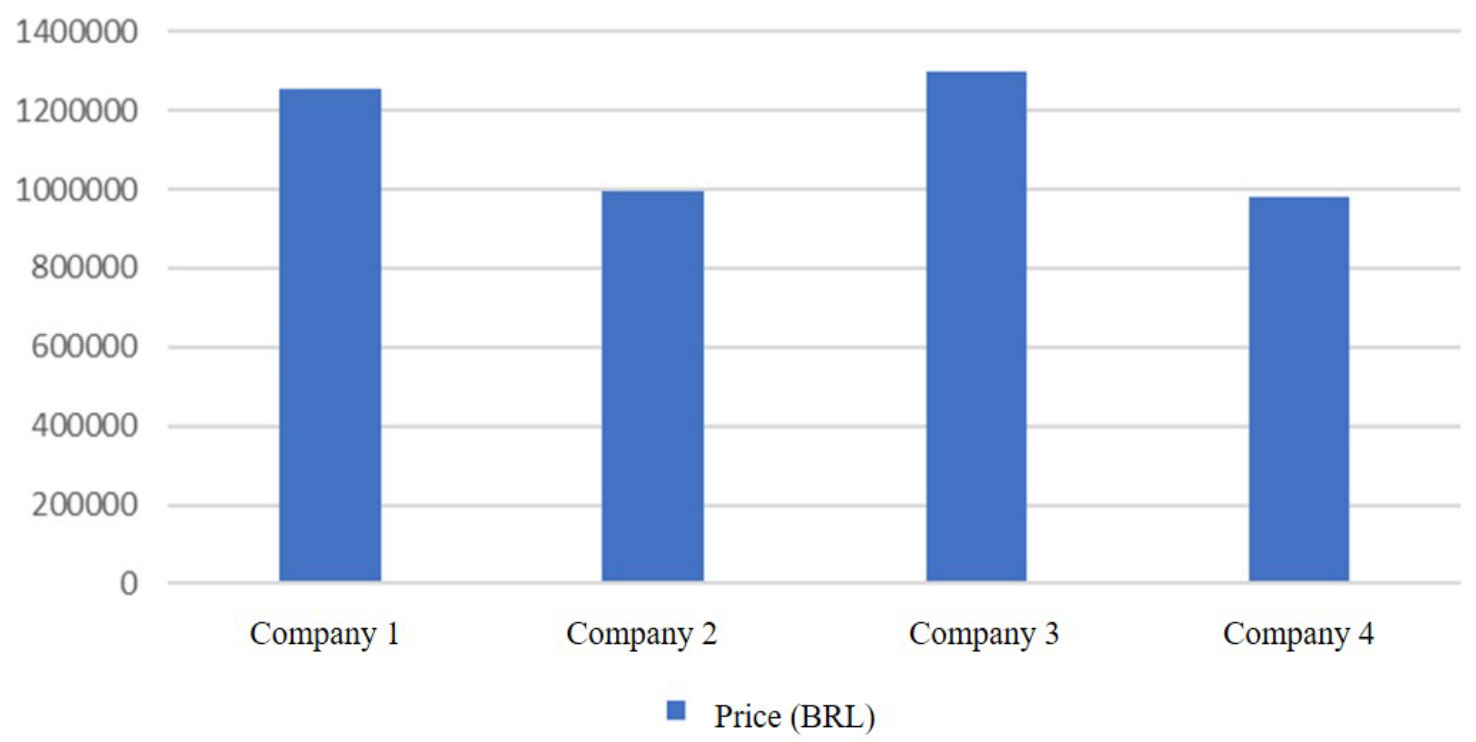

Fig. 3 Comparative of total price per company.

A total of $2,712.00 \mathrm{~m}^{3}$ of self-leveling mortar was spent in the project. The concrete plant could produce the mortar so that the value per $\mathrm{m}^{3}$ was 179.22 BRL. Therefore, the amount spent on the supply of self-leveling mortar for the 5 towers was 486,044.64 BRL. The average floor thickness of the project was 5 $\mathrm{cm}$.

The cost to perform the traditional underlayment in areas where it was necessary to have a difference in floor (bathrooms and balconies) was also considered. Figs. 4-6 illustrate the internal areas of an apartment where there is no possibility of using the self-leveling underlayment by drawing a green hatch. The rooms, kitchens, balconies and bathrooms received ceramic tile (porcelain tile), the rooms and circulations had the laminate flooring as their final coating.

Summing all these areas, a total of $11,206.77 \mathrm{~m}^{2}$ was obtained. The company responsible for executing this service established a value of $30.00 \mathrm{BRL}$ per $\mathrm{m}^{2}$ of underlayment, and the cost of buying the bagged mortar was approximately 21.00 BRL per $\mathrm{m}^{2}$. Therefore, the total cost to execute the remaining areas was of 571,545.27 BRL.

Based on data from past projects that only made use of traditional underlayment to regularize concrete slabs, it is possible to establish an approximate value of 49.77 BRL per $\mathrm{m}^{2}$ of underlayment, considering the cost of the material and also of the team. Thus, for the execution of the entire condominium with the use of the traditional method for underlayment, would result in a cost of 3,270,225.94 BRL. Table 4 summarizes the composition of the costs of the two types of underlayment illustrating the cost disparity between the two underlayment execution methodologies. 


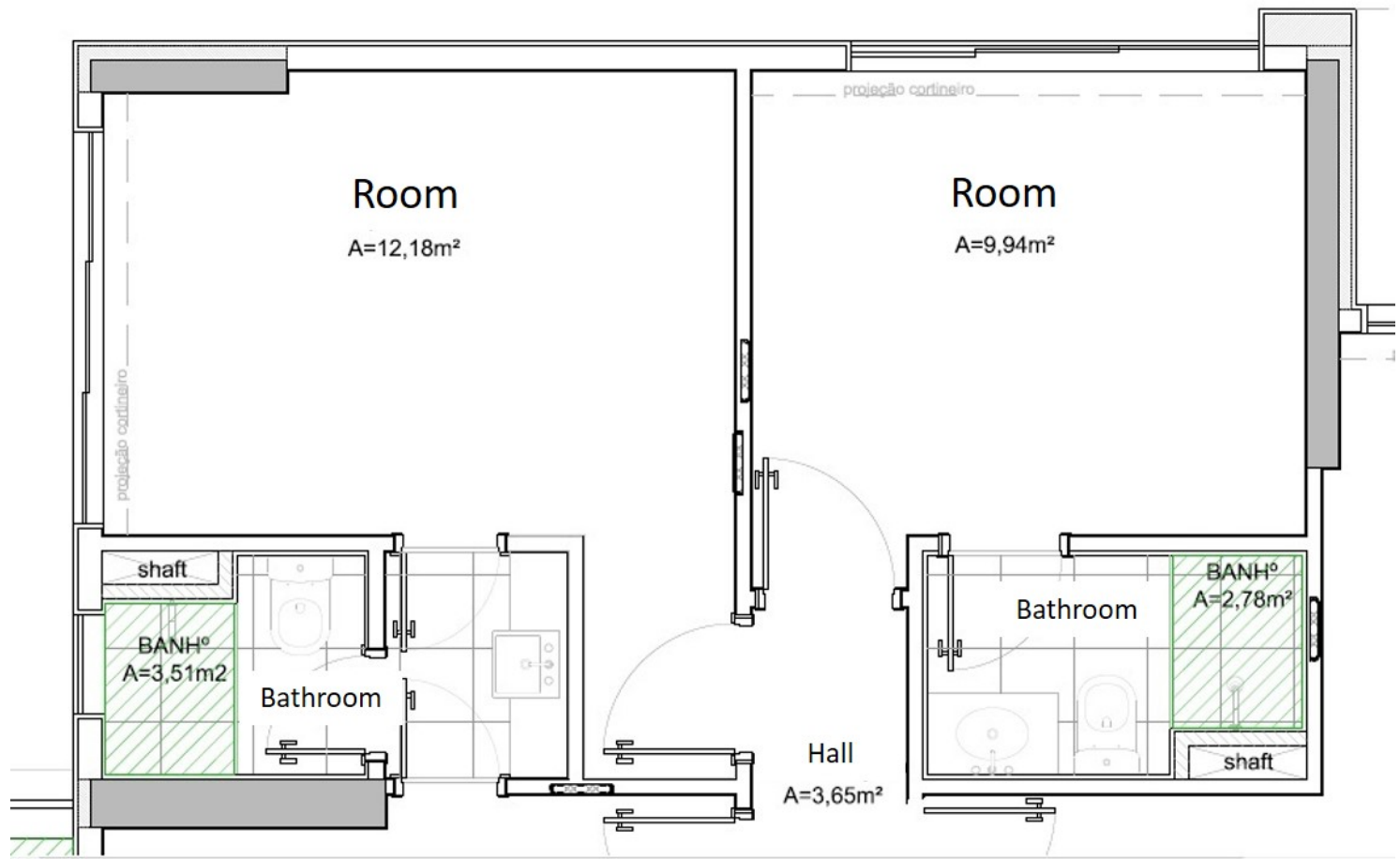

Fig. 4 Areas where the self-leveling underlayment was not used (1).

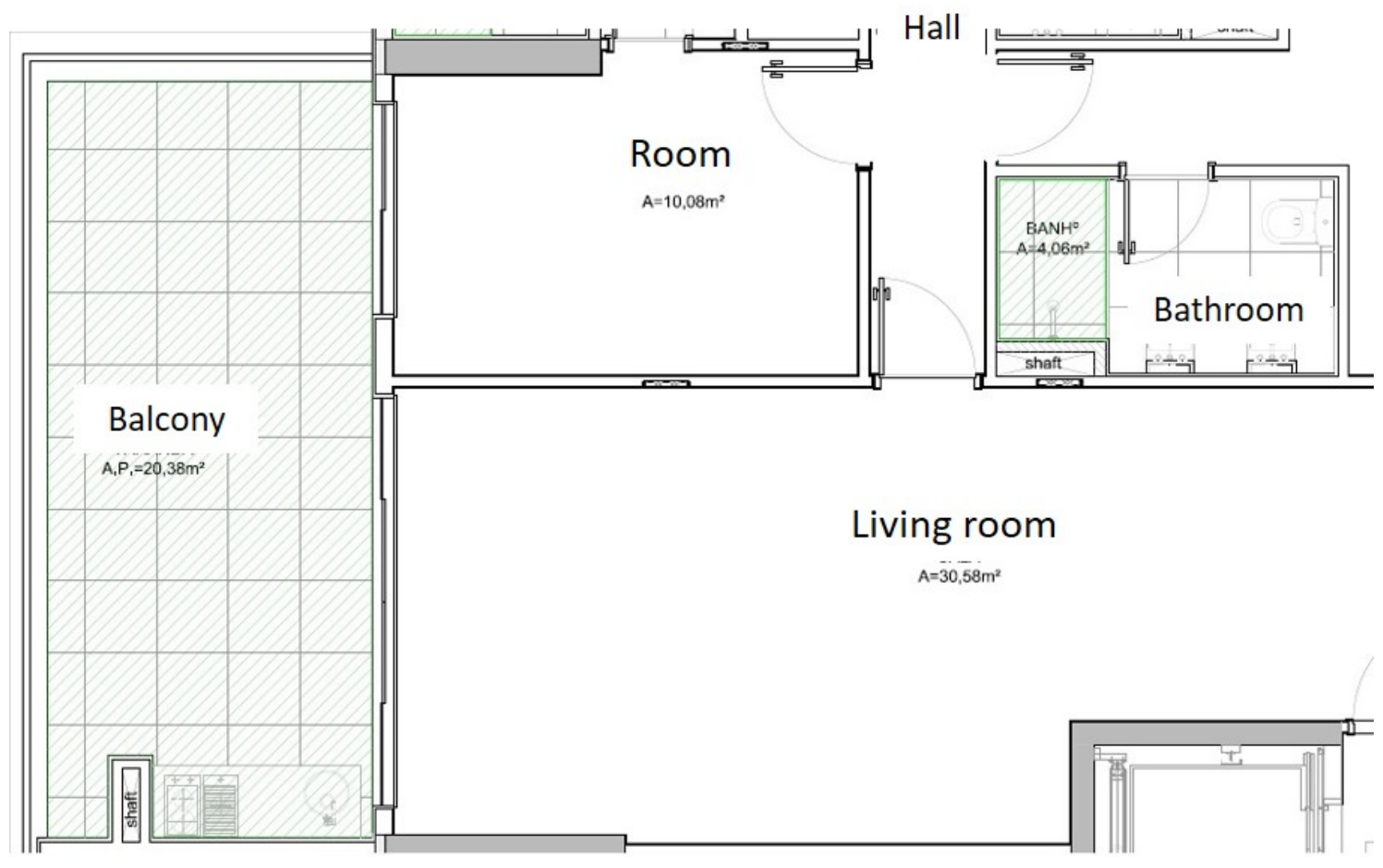

Fig. 5 Areas where the self-leveling underlayment was not used (2). 


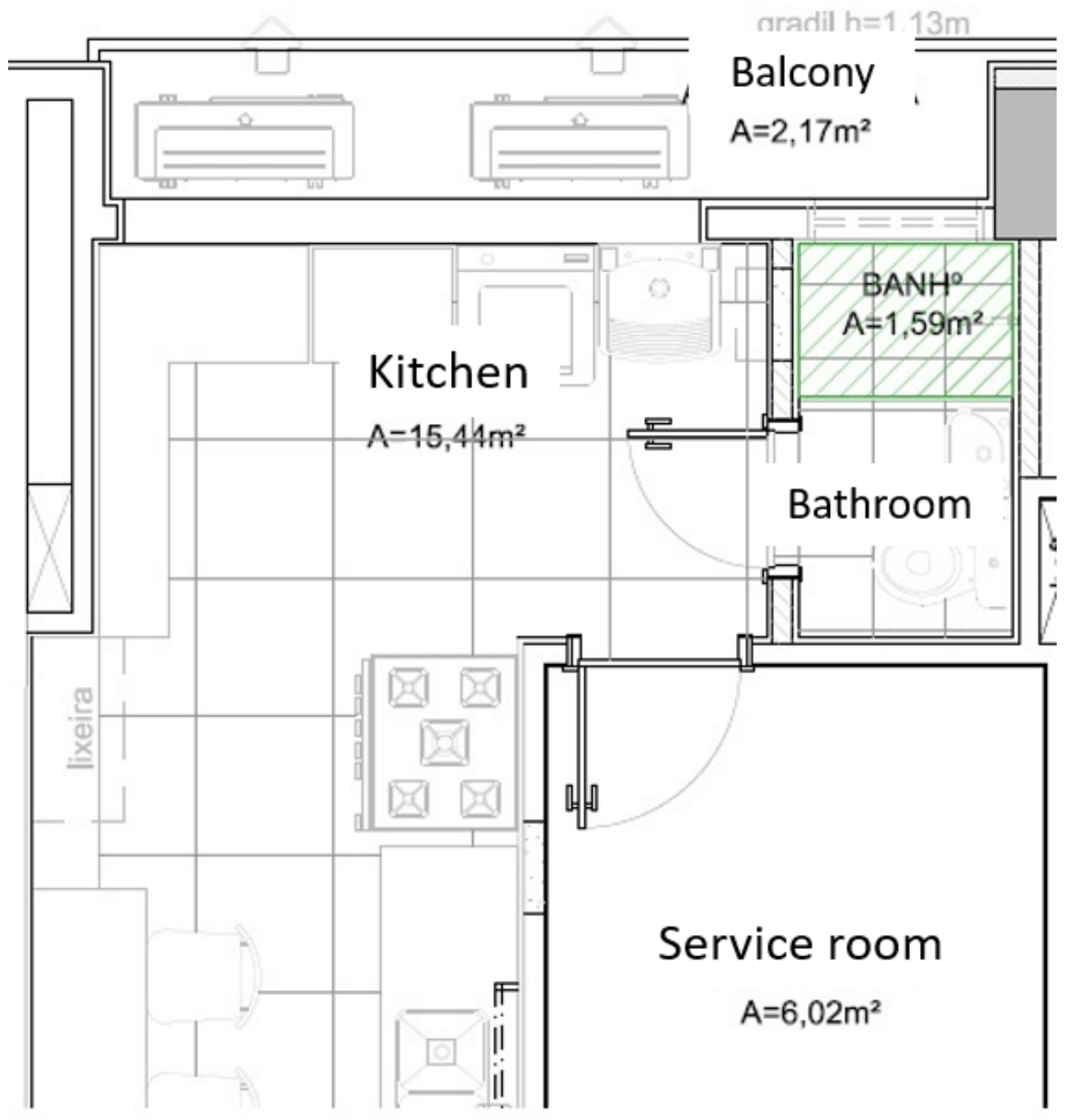

Fig. 6 Areas where the self-leveling underlayment was not used (3).

Table 4 Composition of cost of underlayment.

\begin{tabular}{lll}
\hline Item & Self-leveling underlayment (BRL) & Traditional underlayment (BRL) \\
\hline Material & $486,044.64$ & $1,233,316.07$ \\
Team & $981,000.00$ & $2,036,909.87$ \\
Material (non self-leveling areas) & $336,206.10$ & - \\
Team (non self-leveling areas) & $235,342.17$ & - \\
Total & $2,038,592.91$ & $3,270,225.94$ \\
\hline
\end{tabular}

\section{Final Considerations}

The work showed that the use of the self-leveling underlayment was advantageous in terms of productivity and cost, showing itself as a potential methodology for future projects. Regarding productivity, a significant reduction of the time spent with the execution of the activity has been proven. A reduction of at least $39.7 \%$ was observed in the time spent to perform the service in one of the buildings of the condominium. This reduction of time was evaluated as a very positive point of this methodology, given the great competitiveness among real estate companies. Noting that the comparison made between the two methods considered that the two teams had similar strengths. 
Regarding of cost, a significant reduction of approximately 1,231,633.03 BRL has also been proven, which represents a $37.7 \%$ savings in relation to the amount that would be spent if the project adopts the traditional underlayment method. Given the current economic situation of the country, an economy of this value was very positive for the construction company responsible for this work. There is still a potential to evaluate and identify the best methodology in terms of quality, aspects of adhesion, appearance of hollow regions and among other characteristics.

\section{Reference}

[1] British Standard Institution. 2008. BS 8204. "Part 1:
In Situ Floorings-Code of Practice for Concrete Bases and Screeds to Receive in Situ Floorings.” London.

[2] Fiorito, A. 2009. Manual de Argamassas e Revestimentos: Estudos e Procedimentos de Execução. São Paulo: Pini.

[3] Associação Brasileira de Normas Técnicas. 2013. NBR 15573. "Parte 3: Requisitos para os sistemas de pisos.” In Edificações habitacionais-Desempenho. Brazil.

[4] Barros, M. M., and Sabbatini, F. H. 1991. "Tecnologia de Produção de Contrapisos para Edifícios Habitacionais e Comerciais.” Dissertação de Mestrado, Escola Politécnica da Universidade de São Paulo.

[5] Cerqueira, N. 2013. “Análise de Desempenho do Contrapiso Autonivelante em Relação ao Sistema Tradicional.” UFMG, Belo Horizonte.

[6] Bauer, L. A. F. 2011. Materiais de Construção Civil. Rio de Janeiro: LTC. 